\title{
The Adoption of Improved Cowpea Varieties in Northern Ghana
}

\section{Esther Wahaga*}

CSIR-Food Research Institute, Accra, Ghana

*Corresponding Author: Esther Wahaga, CSIR-Food Research Institute, Accra, Ghana.

Received: April 10, 2019; Published: June 04, 2019

DOI: 10.31080/ASAG.2019.03.0510

\begin{abstract}
Cowpea, the first crop to be harvested in semi-arid regions is an important food crop that bridges that hunger gap that exists before cereal crops are harvested. This paper assesses the adoption of improved cowpea varieties with farmers in Northern Ghana. Semi-structured interviews were administered to 250 farmers: 230 male and 20 female farmers. A multistage sampling procedure was used to select 4 districts, 8 communities and17 households in each community where quantitative and qualitative data was gathered. Farmers who had a history of cowpea production and communities with a history of access to improved cowpea seeds were interviewed. The questionnaire covered demographic aspects of the survey farm households, their production environment, the factors that influence the adoption or non-adoption of improved cowpea varieties, among other things. Results indicated that all farmers adopted cowpea varieties. With typical adoption attitudes, farmers adopt these varieties gradually which eventually peaks and drops depending on yield, amount of pesticides needed and the incidence of insect pest and diseases. In conclusion, due to the persistence of some pest and diseases on some crops, drought related problems, degrading soil fertility, dwindling farm land due to farm lands being taken over as residential plots, and low yields, farmers have found solace in the cultivation of improved varieties which are mainly high yielding, insect/disease resistant and drought tolerant.
\end{abstract}

Keywords: Early Maturing; Smallholder Farmers; Food; Mixed Cropping; Crop Rotation

\section{Introduction}

Agriculture plays an important role in the economic development of many developing countries. Crops like cereals grains, yam and tubers and leguminous crops are of importance to farmers and society. However, cowpea stands out because of its importance to farmers as a cash and food crop, to society as a source of protein and the ability of farmers to harvest before other crops. Cowpea (Vigna unguiculata L. Walp.), is a leguminous crop mostly produced in the semi-arid regions of Africa, Asia and South America [1] and for that matter an important crop in the economy of Northern Ghana. It is the first crop harvested to bridge the hunger gap that exists between harvest of staple cereals from one cropping season and the next thus offering farmers great flexibility [2]. According to Singh., et al. [3], some cowpea varieties are early maturing, bridging the hunger period when food availability can become particularly scarce in semi-arid regions of Sub-Saharan Africa. Cowpea is considered an important component in the diet of most smallholder farmers because, the leaves, immature pods, fresh seeds, and the dry grain are popularly eaten or marketed [4], in cowpea growing areas and in Northern Ghana.

Its seeds are a good source of proteins and vitamins and have the potential to reduce malnutrition [5] among resource poor farmers and for that matter bridge the food and nutrition insecurity gap among vulnerable groups. Thus, making it a lowcost nutritious food for humans, animals and even crops planted after cowpea. A greater proportion of farmers in Northern Ghana grows cowpea. This is due to its importance as a food and nutrition security crop and a source of cash for farm households in Northern Ghana. Besides the grain, cowpea fodder is used to sustain livestock and plays an important role in fixing nitrogen to the soil thereby improving the cultivation of cereal crops like sorghum, millet and maize when grown in rotation [6-8]. According to Ndungu., et al. [9] typically, cropping cowpea involves alternate row cropping of cereals like sorghum, maize and millet to improve soil fertility. 
Soils in semi-arid regions are not fertile due to the nutrient depletion which is attributable to the diminutive mineral and organic fertilizer use by resource poor farmers [9]. However, cropping cowpea in semi-arid conditions improves soil fertility through nitrogen fixation and addition of soil organic matter.

However, the production of cowpea is constrained. Notwithstanding the potential for increased yield, cowpea production is challenging [8]. Several problems including insect pest attacks, disease infestation and droughts [10] inhibits its production. The International Institute of Tropical Agriculture [11], indicates that cowpea production is saddled with insect pest/ diseases in every stage of its life cycle attributing to low yields.

Agricultural research activities over the years have been directed at developing technologies to increase crop production. Notable among these technologies is the development and introduction of improved varieties. SARI has put in a lot of effort to develop, test and disseminate new cowpea varieties for smallholder resource poor farmers. This is not done in isolation of only breeders but a multi-disciplinary team, most often consisting of farmers at the beginning and end of the product development, testing and dissemination. This is usually done by monitoring the perception of farmers on new varieties through on farm trials. This ensures farmers' acceptance and for that matter, a high adoption rate.

In rural areas, agricultural technology could be a means of increasing production for that matter the income of small-holder resource poor farmers. However, Kamara., et al. [12] reported that the constrained use of improved varieties in cowpea growing areas could be as a result of inadequate information on the use of improved cowpea varieties. Also, varieties may not be suitable for an area and seeds of improved varieties may not be widely distributed and consumer demand for such varieties may not be high due to taste or flavour issues.

Even though several improved varieties of the crop have been introduced to farmers over the years, little is known about the extent to which these varieties are adopted. Yet the extent of adoption and constraints to adoption of new technologies are very important in guiding technology development as well as finetuning technologies already developed. Here again, significant variations are evident in adoption rates among different practices and categories of practices [13]. A study conducted by Larochelle., et al. [13] indicated that the adoption of an agricultural technology could be statistically associated with age, farm income, farmland location, skills training and degree of community participation. They further explained that high adoption rates occur for easy to practice technologies compared to complex ones.

This paper assesses the adoption of improved cowpea varieties with farmers who participated in on-farm trials organised by SARI in Northern Ghana. This was to determine if farmers continued the use of such varieties after the trials and if they had transferred the use of such varieties to other farmers.

\section{Methodology of the study}

Semi-structured interviews were undertaken at the community level. In total, 250 farmers from 8 communities were involved in the interviews: 230 male and 20 female farmers.

Eight communities were randomly selected from four district in the Northern Region of Ghana. Research methods relevant to the research aim, objectives and questions were used in primary data collection. Questionnaire covered demographic aspects of the survey farm households, their production environment, the factors that influence the adoption or non-adoption of improved cowpea varieties, among other things.

Farmers who had a history of cowpea production and communities with a history of having access to improved cowpea seeds were interviewed. Multistage sampling procedure was used, where the region and districts were first purposely selected and the communities randomly selected. Households were purposely selected to include cowpea farmers in general and farmers who were involved in SARI's varietal on farm technology transfer. 17 households were selected from each community, consisting of 10 households who had been involved in SARI's activities and 7 who had never been involved in SARI's activities but cultivated cowpea. Respondents were aged 20-68. Female respondents were mostly widowed with just one renting her field for cowpea production. Both quantitative and qualitative data were gathered and made use of in this study where descriptive statistics were used to characterize farm households.

\section{Results and Discussion}

\section{Cowpea cropping systems in Northern Ghana}

Cowpea production in Northern Ghana is mainly to serve as a source of food for farm household; it bridges the hunger gap. However, some households would produce cowpea to supplement other sources of income if yields are good. The More frequently farmers grow cowpea to meet the dual objective of satisfying both 
household food needs and realizing cash income from the sale of the crop. To a lesser extent some farm households grow cowpea because other upland crops are failing. Table 1 indicates the reasons for cowpea production.

\begin{tabular}{|l|c|c|c|}
\hline \multicolumn{1}{|c|}{ Purpose } & Frequency & Percentage & Cumulative \\
\hline Mainly food & 43 & 17.2 & 17.2 \\
Mainly cash & 23 & 9.2 & 26.4 \\
Cash and food & 172 & 68.8 & 95.2 \\
Other crops failing & 12 & 4.8 & 100 \\
Total & 250 & 100 & \\
\hline
\end{tabular}

Table 1: Reasons for Cowpea Production.

\section{Field Data}

Cowpea may be grown as a sole or mixed crop. However, improved cowpea which are not crawly, are planted as sole crops. This system of cropping improved cowpea enables the spraying of pesticides. Farmers were aware that improved cowpea varieties would not yield well if not sprayed with pesticides. With farmer(local) varieties, extensive intercropping with cereals was practiced. Of the sampled household heads interviewed, all indicated that they grow improved cowpea in pure stands. This is an indication that, the technology of planting improved cowpea varieties in pure stand had been adopted. Of the 250 respondents, only 76 grew local cowpea varieties, which they intercrop with crops like sorghum, maize, millet, yam and cassava. Out of the 76 farmers who indicated that they intercrop cowpea with other crops, 61 of the respondents (80.3\%) used sorghum as the intercrop (table 2). These other crops have also seen improvements in terms of varietal developments to enhance yield. In the same way, these varieties have been transferred to farmers for onward adoption where various forms of adoption have occurred.

\begin{tabular}{|l|c|c|c|c|}
\hline \multicolumn{1}{|c|}{ Crop } & Frequency & Percentage & $\begin{array}{c}\text { Cumulative } \\
\text { Percentage }\end{array}$ & $\begin{array}{c}\text { Improved } \\
\text { Variety\% }\end{array}$ \\
\hline Sorghum & 61 & 80.3 & 80.3 & 76.3 \\
Maize & 10 & 13.2 & 93.4 & 13.2 \\
Millet & 2 & 2.6 & 96.1 & 0 \\
Casssava & 1 & 1.3 & 97.4 & 1.3 \\
Yam & 2 & 2.6 & 100 & 0 \\
\hline
\end{tabular}

Table 2: Crops Grown with Cowpea.

Field Data
Improved cowpea varieties in cultivation in Northern Ghana

Data indicated that improved cowpea varieties grown by farmers in the study area were Vallenga, Bengpla, Marfo-tuya, Apagbala, Padi-tuya, Songotra, Bawutawuta and Zaayura. All 250 of the farmers interviewed indicated that they grow improved cowpea varieties. However, 30.4\% cultivation local varieties alongside improved varieties. Due to the virility of improved varieties compared to local varieties which are mostly susceptible to disease, insects and drought, improved varieties have become popular with farmers in Northern Ghana. Though $100 \%$ of the respondents produce improved varieties of cowpea, some of the improved varieties were preferred to others. For instance, Apagbala, Vallenga, Bengpla were fading out, Padi-tuya was adopted because it had a delicious taste and Songotra had been leading for three years (2013-2016) because it was high yielding though embattled with disease (table 4) in the last two years. Data showed that Bawutawuta and Zaayura were the highly adopted varieties at the time of the study (Table 3). Varieties that had been released earlier (Vallenga) had a smaller proportion of farmers adopting compared to those recently (Zaayura) released varieties. However, this does not mean it is always the trend. The variety, Songotra which was relatively recently release is falling behind in terms of adoption because, there had been severe aphid infestation following its release. Again, varieties (Bengpla, marfo-Tuya and Apagbala) which had been released long before Songotra have had better adoption rates compared to Songotra.

\begin{tabular}{|l|c|c|}
\hline \multicolumn{1}{|c|}{ Variety } & Frequency & $\begin{array}{c}\text { Percent of } \\
\text { sample }\end{array}$ \\
\hline Vallenga & 34 & 13.6 \\
\hline Bengpla & 47 & 18.8 \\
\hline Marfo-tuya & 43 & 17.2 \\
\hline Apagbala & 41 & 16.4 \\
\hline Padi-tuya & 61 & 24.4 \\
\hline Songotra & 39 & 15.6 \\
\hline Bawutawuta & 78 & 31.2 \\
\hline Zaayura & 87 & 34.8 \\
\hline Total & 430 & 172 \\
\hline
\end{tabular}

Table 3: Proportion of farmers Adopting Improved cowpea varieties in 2016.

Field Data. Note: Some farmers cropped more than one variety 


\begin{tabular}{|c|c|c|c|}
\hline Variety & Maturity Period & Characteristics & Date Released \\
\hline $\begin{array}{l}\text { Farmers Variety } \\
\text { (Local) }\end{array}$ & $75-80$ & $\begin{array}{ll}\text { - } & \text { Low yielding } \\
\text { - } & \text { High fodder yields } \\
\text { - } & \text { Long maturity periods }\end{array}$ & \\
\hline Vallenga & 60 & - High grain/fodder yields. & 1985 \\
\hline Bengpla & $55-60$ & $\begin{array}{ll}\text { - } & \text { High grain/fodder yields } \\
\text { - } & \text { Susceptible to cowpea stem rot }\end{array}$ & 1992 \\
\hline Marfo-tuya & $66-70$ & $\begin{array}{l}\text { - } \text { High grain/fodder yields in low fertile lands } \\
\text { - } \text { Resistant to heat } \\
\text { - } \quad \text { Resistant to S. gesnerioides }\end{array}$ & 2002 \\
\hline Apagbala & 60 & $\begin{array}{l}\text { - High fodder/grain yield, -Susceptible to Striga } \\
\text { and aphids }\end{array}$ & 2002 \\
\hline Padi-tuya & $64-67$ & - Moderately resistant to insects/diseases/striga. & 2008 \\
\hline Songotra & $62-65$ & $\begin{array}{l}\text { - Highly resistant to Striga, } \\
\text { - Moderately resistant to most insects/diseases } \\
\text { - Susceptible to aphids. }\end{array}$ & 2008 \\
\hline Bawutawuta & $69-75$ & $\begin{array}{l}\text { - } \text { Highly resistant to Striga } \\
\text { - } \quad \text { Moderately resistant to most insects/diseases } \\
\text { - } \quad \text { Susceptible to aphids. }\end{array}$ & 2008 \\
\hline Zaayura & $64-67$ & $\begin{array}{l}\text { - Highly resistant to aphids, } \\
\text { - Moderately resistant to other insects, diseases } \\
\text { and striga. }\end{array}$ & 2008 \\
\hline
\end{tabular}

Table 4: Cowpea Varieties Under Cultivation.

Field Data

Trends in the adoption of improved cowpea varieties

Farmers mentioned several constraints to the adoption of improved cowpea varieties. The most important constraints relate to access to improved seed and pests and disease management. Fifty percent of the farmers interviewed stated that the adoption of improved cowpea varieties require the use of costly chemical pesticides. Most farm households find it difficult to purchase pesticides. Results indicated that when the cost of producing a variety increases due to insect pest and disease infestation, farmers tend to disadopt or reduce the quantities produced of such varieties. Where farmers can purchase pesticides, the next bottle neck is access to spray equipment as indicated by $56 \%$ of respondents. Another pest related constraint mentioned by $10 \%$ of the respondents was that improved cowpea varieties were with time susceptible to field pests and diseases compared to local varieties. Again, seeds of improved varieties were more expensive compared to local varieties according to $89 \%$ of the respondents.

A cumulative adoption curve (logistic curve) was constructed to illustrate the adoption rate of improved cowpea varieties over the period 2012 to 2015. The cumulative adoption curve (figure 1) below suggests the typical S-Shape which is characteristic of adoption over time. With typical adoptions, people tend to adopt slowly and eventually slow down until an improved variety are introduced. This is when varieties are no longer resistant to pest and diseases. This behaviour is what incites the development of new varieties or improvement on old varieties. Farmers had grown the various varieties for several years after their release and were still growing them. Results showed that the intensity of adoption (figure 1) builds up slowly and eventually peaks and reduces after new and more vigorous varieties are developed and released or until the adopted variety is attacked by pest and diseases. 
For instance, Vallenga, though released in 1985 is still in cultivation, though more vigorous varieties have been released, by a small number of farmers (13.6\%) as compared to Zaayura (34.8\%) released in 2008.

Other crops have seen varietal improvements in the study area and farmers have adopted them. For instance, farmers had adopted improved varieties of sorghum, cassava and maize depending on access to the varieties, willingness to adopt and suitability of the variety. These new varieties are mostly adopted because they are the main staple crops or cash crops. Other reasons for adoption were varieties being disease and insect pest tolerant, drought resistant and high yielding. These were for all crops including cowpea (table 5). In terms of cropping for cash and food, farmers would often look out for crops that are high yielding. Though farmers did not irrigate their crops, they did not pay attention to varieties that were drought resistant despite rains not being reliable in the study area.

\begin{tabular}{|c|c|c|}
\hline Reason & Frequency & Percentage \\
\hline Yield & 198 & 79.2 \\
Disease and insect pest tolerant & 159 & 63.3 \\
Drought resistant & 54 & 21.6 \\
\hline
\end{tabular}

Table 5: Reasons for adopting improved crop varieties. Field Data

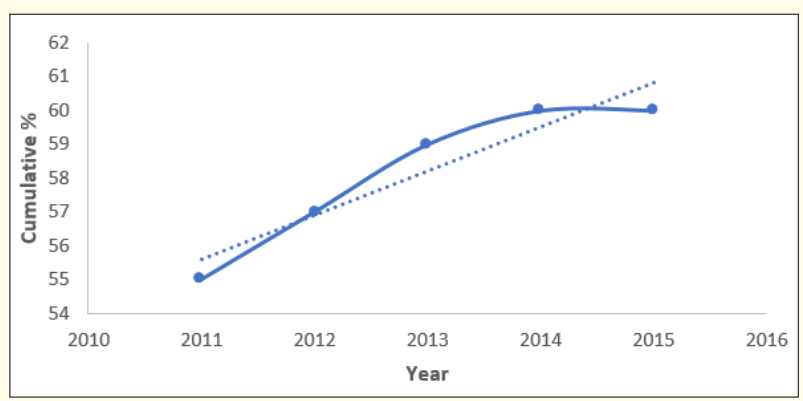

Figure 1: Cumulative Adoption Curve for Songotra Cowpea.

$$
\text { Field data }
$$

Factors affecting the adoption of improved cowpea varieties

Farm size and household size were positively significant in determining to what extent farmers would adopt improved varieties. Those with large farm sizes cultivated more than two varieties compared to those with smaller farm size. Farmers who had smaller farm sizes thoroughly considered all varieties available to them and which ones could offer high yields while considering drought and pest and diseases. Whereas farmers with large farmers could risk producing any variety hoping to get high yields. However, having a large farm and doing just any variety depended on the number of people in the household. Where, there were many household members, farmers with large farm sizes would behave in the same way as those with small farm lands.

Age did not play any significant role in adoption, since older farmers were careful what they adopted. It was found that, most of the older farmers 57 years and above still held on to the local varieties indicating that older farmers are risk averse compared to younger ones. Muyanga [14] indicated that older farmers may have rich farming experience and built assets to use as collateral securities putting them in a position to access loans to adopt improved technologies/varieties than younger farmers. However, Caswell., et al. [15] showed that technology adoption and its subsequent benefits requires time which can reduced the interest of older farmers thus, Bamire., et al. [16] argues that younger farmers could be more willing to take risks and patiently wait for the right time to reap the benefit of adopting new technology.

Extensions services did not also play any significant role because they were barely non-existent. For the past five years farmers reported of not receiving any extension services but rather they would travel to the districts to find Agricultural extension help if there were pest and diseases problems with their crops. Though little to no help was reported where such incidents were directed to Agricultural Extension Services.

Farm income was a determinant of which varieties to adopt as some of the varieties needed more sprays and monitoring than others. See table 4 which indicates the characteristics of each variety.

The pattern of female adopters did not differ from male adopters as female adopters behaved in the same way as the male adopters. For instance, considering the adoption pattern of both male and female, it was noted that females as well as the male adopters would gradually adopt a variety until it peaks and eventually reduce the intensity of production when yields reduces. Therefore, gender did not have a significant influence on the pattern of adoption between male and females when it came to the adoption of cowpea varieties.

The cultivation of improved cowpea and other crop varieties have improved the livelihoods of farmers in terms of income and nutrition. Not only that, society has also benefited in diverse ways through the cultivation of improved varieties which results in 
higher yields. As a result, farmers can sell excess farm proceeds which provides employment to wholesalers, retailers, small and medium scale entrepreneurs and processors. The nutritional value of cowpea comes into play, where the protein nutritional requirements of individuals can be achieved through the consumption of cowpea, especially children.

\section{Conclusion}

In conclusion, due to the persistence of some pest and diseases on some crops, drought related problems, degrading soil fertility, dwindling farm land due to farm lands being taken over as residential plots, and low yields, farmers have found solace in the cultivation of improved varieties which are mainly high yielding, insect/disease resistant and drought tolerant. This therefore explains why farmers are willingly shifting from or adding on to local varieties.

This study has brought to light the factors affecting the adoption of improved cowpea varieties in Northern Ghana. It has shown that although farmers grow improved cowpea varieties, local varieties are still very prominent in the production system. This is illustrated by the high proportion of farmers growing local cowpea varieties. The study also highlights the constraints that are faced by potential adopters of improved cowpea varieties. Since these constraints relate directly to pests and disease infestation and pests and disease management, efforts need to be directed at developing pest tolerant and pest resistant cowpea varieties.

The importance of cowpea as a cash crop as mentioned by respondents of the questionnaire survey needs to be considered. Attention would have to be given to developing varieties that meet the demands of consumers. Finally, it can be said conclusively that there is a potential for increased adoption of improved cowpea varieties in Northern Ghana particularly in those areas where land is not a limiting factor and farmers have access to pesticides.

From the results it is observed that it did not matter whether a farmer was part of SARI's on-farm trial, they all adopted the newly introduced cowpea varieties in the same way. This is not to downplay the significance of on-farm trials. They are because, technologies are transferred during on-farm trials for onward transfer to other farmers by participating farmers in on-farm trials.

It is recommended that farmers should have a closer working relationship with research through agricultural extension staff for concerns to be channelled to facilitate better research into varietal development. However, this remains a problem since extension farmer ration is not encouraging.

\section{Bibliography}

1. Sani A., et al. "Socio-economic factors influencing adoption of dual-purpose cowpea production technologies in Bichi Local Government Area of Kano State, Nigeria”. Asia Journal of Agricultural Extension Economics and Sociology (2014): 258-273.

2. Coulibaly 0., et al. "Baseline assessment of cowpea breeding and seed delivery efforts to enhance poverty impacts in SubSaharan Africa (Report)" (2010).

3. Singh BB., et al. "Improving the production and utilization of cowpea as food and fodder". Field Crop Research 84 (2003): 169-177.

4. Moalafi AI., et al. "Germplasm evaluation and enhancement for the development of cowpea (Vigna unguiculata (L.) Walp. dual-purpose F2 genotypes". (2010).

5. Jayatilake C., et al. "Cowpea; An Overview on its nutritional facts and health Benefits". Journal of the Science of Food and Agriculture 98.13 (2018).

6. Dugje IY., et al. "Farmer's Guide to Cowpea production in West Africa”. IITA Ibadan, Nigeria (2009).

7. International Institute of Tropical Agriculture (IITA). Cowpea project for Africa Research and Development. International Institute of Tropical Agriculture (2009).

8. Tijjani AR., et al. "Adoption of innovative cowpea production practices in a rural area of Katsina State, Nigeria". Journal of Agricultural and Crop Research 3.4 (2015): 53-58.

9. Ndungu SM., et al. Agriculture, Ecosystems and Environment 261 (2018): 161-171.

10. Singh BB., et al. "Recent progress in cowpea breeding". In: Fatokun CA, Tarawali SA, Singh BB, Tamo PM (eds.), Challenges and opportunities for enhancing sustainable cowpea production. Ibadan, Nigeria: IITA (2002): 22-40.

11. International Institute of Tropical Agriculture (IITA). Research for development. Cereals and Legumes Systems. Cowpea (2006).

12. Kamara AY., et al. "A participatory evaluation of improved cowpea cultivars in the Guinea and Sudan Savanna zones of north east Nigeria". Taylor and Francis (Pub.) London W1T3JH, UK (2009). 
13. Larochelle C., et al. "Did You Really Get the Message? Using Text Reminders to Stimulate Adoption of Agricultural Technologies". The Journal of Development Studies 55 (2019): 548-564.

14. Muyanga M. Smallholder adoption and economic impacts of tissue culture banana in Kenya Department of Agricultural, Food and Resource Economics, Michigan State University, 012 Cook Hall, East Lansing MI 48824 USA (2009).

15. Caswell M., et al. Adoption of Agricultural Production practices: Washington DC. US Department of Agriculture. Resource Economics Division, Economic Research service. Agriculture Economic Report No. 792 (2001).

16. Bamire S A., et al. "Impact of promoting sustainable agriculture in Borno (PROSAB) program on adoption of improved crop varieties in Borno State of Nigeria". Journal of Food, Agriculture and Environment 8 (2010): 391-398.

Volume 3 Issue 7 July 2019

(C) All rights are reserved by Esther Wahaga. 